\title{
Endovascular Treatment of Aortic Aneurysms and Blood Transfusion. What do We Need?
}

\author{
Tratamento Endovascular de Aneurismas da Aorta e \\ Transfusão de Sangue. $O$ que Precisamos?
}

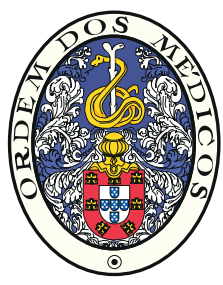

Rui MACHADO ${ }^{1}$, Luís LOUREIRO ${ }^{1}$, Inês ANTUNES ${ }^{1}$, Jorge COUTINHO², Rui de ALMEIDA ${ }^{1}$

Acta Med Port 2016 May;29(5):310-314 - http://dx.doi.org/10.20344/amp.7283

ABSTRACT

Introduction: Comparatively to open repair, endovascular aneurysm repair has reduced transfusion rates but there's no recommendation about number of red blood cells units to be crossmatched preoperatively. Our aim is contribute to the analysis of red blood cells units needs in endovascular and hybrid aortic aneurysm repair and developing a protocol for maximum surgical blood orders schedule.

Material and Methods: We retrospectively analyzed our prospective database of elective endovascular aneurysm repair from 2001 to 2012. We analyzed patients' age, gender, ASA classification, maximum surgical blood orders schedule, red blood cells units transfused and timings, types of endoprosthesis, red blood cells units consumption/endoprosthesis' type ratio, crossmatch to transfusion ratio, conversion to open repair, hemoglobin concentrations before surgery and discharge.

Results: We selected 187 patients, 90\% men, mean age 73.1, ASA mode III. The endoprosthesis were aorto-bi-iliac in 71\%, aorto-uniiliac in $23 \%$ and thoracic in $6 \%$. Of these, $72.6 \%$ of the patients did not require blood transfusion. We transfused 171 red blood cells units. Crossmatch to transfusion ratio was 10.1 until 2010 and 7.3 after. The ratio of red blood cells units consumption/endoprosthesis in the first 24 hours was 0.21 red blood cells units/aorto-bi-iliac, 0.46 red blood cells units/aorto-uni-iliac, 0.8 red blood cells units/thoracic, 1.3 red blood cells units/hybrid-thoracic and 2 red blood cells units/hybrid-aorto-bi-iliac. A statistical correlation was observed between red blood cells units transfused postoperatively and type of endoprosthesis $(p<0.001)$ and between ASA classification and red blood cells units transfused after 24 hours $(p<0.01)$.

Discussion: Guidelines from the British Society of Haematology are based on a crossmatch to transfusion ratio of 2:1. Our crossmatch to transfusion ratio was 10.1 until 2010 and 7.3 from 2011 to 2012.

Conclusion: These results changed our policy of maximum surgical blood orders schedule for endovascular aneurysm repair. We now type and screen aorto-bi-iliac and aorto-uni-iliac. We crossmatch two red blood cells units for thoracic, three red blood cells units for hybrid thoracic and four red blood cells units for hybrid abdominal procedures. This may lead to financial savings, improved efficiency and reduce workload in hematology department.

Keywords: Aortic Aneurysm/surgery; Blood Transfusion; Clinical Protocols; Endovascular Procedures.

\section{RESUMO}

Introdução: O tratamento endovascular dos aneurismas da aorta reduziu as taxas de transfusão. Não existem recomendações relativamente às unidades de glóbulos vermelhos a serem tipadas por crossmatch pré-operatoriamente. O nosso objetivo é contribuir para a análise das unidades de glóbulos vermelhos necessárias no tratamento endovascular dos aneurismas da aorta e na cirurgia híbrida de aneurismas da aorta e definir um protocolo do Maximum Surgical Blood Orders Schedule.

Material e Métodos: Analisámos retrospetivamente a base de dados prospectiva dos doentes tratados eletivamente por tratamento endovascular dos aneurismas da aorta, entre 2001 e 2012. Analisamos idade, género, classe ASA, Maximum Surgical Blood Orders Schedule, unidades de glóbulos vermelhos transfundidas e tempos, endoprótese, relação unidades de glóbulos vermelhos consumidas/endoprótese, relação unidades crossmatched/transfundidas, conversão para cirurgia convencional, hemoglobina pré-operatória e na alta.

Resultados: Selecionamos para análise 187 doentes, 90\% homens, idade média 73,1, classe ASA III mais frequente. Usamos próteses aorto-bi-iliaca em $71 \%$, aorto-uni-iliaca $23 \%$ e torácica $6 \%$. Não necessitaram transfusão $72,6 \%$. Transfundimos 171 unidades de glóbulos vermelhos. A relação unidades crossmatched/transfundidas foi 10,1 até 2010 e 7,3 após. A relação unidades de glóbulos vermelhos consumidas/endoprótese nas primeiras 24 horas foi 0,21 unidades de glóbulos vermelhos/aorto-bi-iliaca, 0,46 unidades de glóbulos vermelhos/aorto-uni-iliaca, 0,8 unidades de glóbulos vermelhos/torácica, 1,3 unidades de glóbulos vermelhos/híbrida-torácica e duas unidades de glóbulos vermelhos/híbrida-aorto-bi-iliaca. Obtivemos relação estatisticamente significativa entre unidades de glóbulos vermelhos transfundidas/endoprótese $(p<0,001)$ e entre classificação ASA e unidades de glóbulos vermelhos transfundidas após $24 \mathrm{~h}(p<0,01)$.

Discussão: As recomendações da British Society of Haematology baseiam-se numa relação unidades crossmatched/transfundidas de 2:1. Na nossa instituição, a relação unidades crossmatched/transfundidas foi de 10,1 até 2010 e 7,3 de 2011 a 2012.

Conclusões: Os resultados mudaram o nosso Maximum Surgical Blood Orders Schedule para o tratamento endovascular dos aneurismas da aorta. Atualmente procedemos ao teste "type and screen" para próteses aorto-bi-iliaca e aorto-uni-iliaca e a testes de crossmatch de duas unidades de glóbulos vermelhos para torácica, três para híbrida-torácica e quatro para híbrida-abdominal. Isto pode levar a menos gastos, aumento de eficácia e reduzir a sobrecarga no departamento de hematologia.

Palavras-chave: Aneurismas da Aorta/cirugia; Procedimentos Endovasculares; Protocolos Clínicos; Transfusão de Sangue.

\footnotetext{
1. Angiology and Vascular Surgery Department. Hospital Geral de Santo António. Oporto Hospital Center. Porto. Portugal.

2. Hematology Department. Hospital Geral de Santo António. Oporto Hospital Center. Porto. Portugal.

$\square$ Autor correspondente: Rui Machado.rmvasc@gmail.com

Recebido: 05 de dezembro de 2015 - Aceite: 15 de fevereiro de 2016 | Copyright @ Ordem dos Médicos 2016
} 


\section{INTRODUCTION}

Endovascular aneurysm repair (EVAR) was originally developed for patients considered ineligible for open surgical repair. ${ }^{1}$ Since then, this minimally invasive method of treatment has become the first choice for anatomical suitable aortic aneurisms.

EVAR is associated with a lower morbidity, mortality, hospital stay and blood loss. ${ }^{2-4}$ Blood loss in EVAR is due to sheaths, catheters and delivery system exchanges ${ }^{5}$ or surgical complications (access related problems, aneurysm or iliac artery rupture or inaccurate device deployment). In 2013 Montán et al, concluded that open femoral artery access, branched and uniiliac endografts, introducer size and aneurysm diameter were all associated with more perioperative bleeding. ${ }^{6}$ Also, up to $10 \%$ of elective EVAR from his series had a perioperative blood loss exceeding 1 liter and $2 \%$ over 2 liters, which was independently associated with higher morbidity and mortality. Despite these sources of blood loss, there is clear documented evidence that elective EVAR has reduced blood loss and consequently transfusion rates. Studies suggest that EVAR is associated with a perioperative bleeding between $200-$ $400 \mathrm{~mL}$, lower than 1000-1500 mL observed for open repair

Acute surgical conversion is a rare complication affecting $1.1 \%$ and blood transfusion is required in $69.4 \%$ of these patients. ${ }^{7}$ As it is a rare event it is difficult to study and there is not an at-risk population identifiable. In addition to prolonged operative times and higher transfusion rates, these patients have higher morbidity and mortality rates.

Preoperative request of red blood cells units (RBCU) often overestimates blood loss $^{8}$ and little of requested RBCU is ultimately used which may cause exhaustion of supplies and resources. ${ }^{9}$ Preoperative over-ordering has been documented for nearly 40 years.

Two basic tests could be performed to type blood: the group and screen test that identifies $A B O$ group system and the crossmatch tests that full type the sample of blood. Crossmatched blood is ready to use but is removed from the common pool. Concerning elective procedures it has been reported that only $30 \%$ of crossmatched blood is used which implies a waste of blood and resources.

There are a lot of indices available to evaluate the adequacy of blood ordering and its utilization. In 1975 Boral Henry suggested the use of crossmatch to transfusion ratio (CTR). The transfusion index (TI) is referent to the number of RBCU used per patient crossmatch indicating appropriateness of number of RBCU crossmatched. The maximal surgical blood order schedule (MSBOS) is calculated from the transfusion index and estimates RBCU that will be needed for the procedure and can be implemented based on audits and in agreement between medical teams. By evaluating blood ordering and transfusion rates it was possible to develop MSBOS which serves as a guide to anticipated blood requirements in a surgical procedure and many studies have shown that the institutional implementation of MSBOS have led to a safe and effective reduction in blood ordering.
Mann et al, refers that the majority of vascular units in the United Kingdom crossmatch four to six RBCU for open abdominal aortic aneurysm repair, but there is no recommendation for EVAR. ${ }^{10}$

We analyzed the RBCU needs in our endovascular and hybrid aortic aneurysm repair series and developed a protocol of maximum blood orders fitted to each procedure.

\section{MATERIAL AND METHODS}

A retrospective analysis of our prospective database of elective endovascular aneurysm repair from 2001 to 2012 was performed. We analyzed patients' age, gender, American Society Anesthesiologists physical status (ASA) classification, maximum surgical blood orders schedule, RBCU transfused and timings (first 24 hours postoperative, 24 hours to 48 hours and after 48 hours), crossmatch to transfusion ratio, types of endoprosthesis, RBCU consumption/type of endoprosthesis ratio, conversion to open repair, hemoglobin concentrations before surgery and discharge.

All EVAR were performed in the operative theatre, using C-arm imaging and radiolucent table. A single surgical femoral cut-down was done in the thoracic patients and bilateral in the abdominals.

The database is maintained using Microsoft Excel (Microsoft Corporation, Santa Rosa, Calif) and analyses were performed with SPSS 15.0 software (SPSS Inc, Chicago, III). Mean, median, mode, minimum, maximum and standard deviation values were calculated for the different variables. Correlation between values and statistical significance for each variable studied was obtained using Pearson correlation coefficient. We used the standardized $p$ value $<0.05$ to consider statistically significance.

\section{RESULTS}

Our results tend to follow a normal distribution.

For analysis we selected 187 patients with aortic aneurismal disease treated between 2001 and 2012. Fifteen patients had missing data that led to exclusion of the study.

There was an increase in the numbers of patients treated by year. Since 2009 we treat 30 patients/year.

Of the all, $90 \%$ of the patients were male. The mean age was 73.1 (between 35 to 92 years) (Fig. 1).

The ASA classification varied between II and V (Fig. 2).

The endoprosthesis used were aorto-bi-iliac (ABI) in 121 patients $(71 \%)$, aorto-uni-iliac (AUI) in 40 patients $(23 \%)$ and thoracic (THO) in 11 patients $(6 \%)$. Hybrid surgery represented $55 \%$ ( 6 patients) of the thoracic surgeries and $1.7 \%$ (3 patients) of the abdominal surgeries. We observed a statistical significant relationship between type of surgery and the RBCU transfused $(p<0.001)$ in every time intervals, with a Pearson correlation coefficient, $r$, of 0.52 .

A total of 171 RBCU were transfused, with an average of $0.9 /$ patient. Of these, $36 \%$ of the RBCU were administrated in the first 24 hours after surgery, $34 \%$ between 24 to 48 hours and $30 \%$ after 48 hours. $72.6 \%$ of patients weren't 

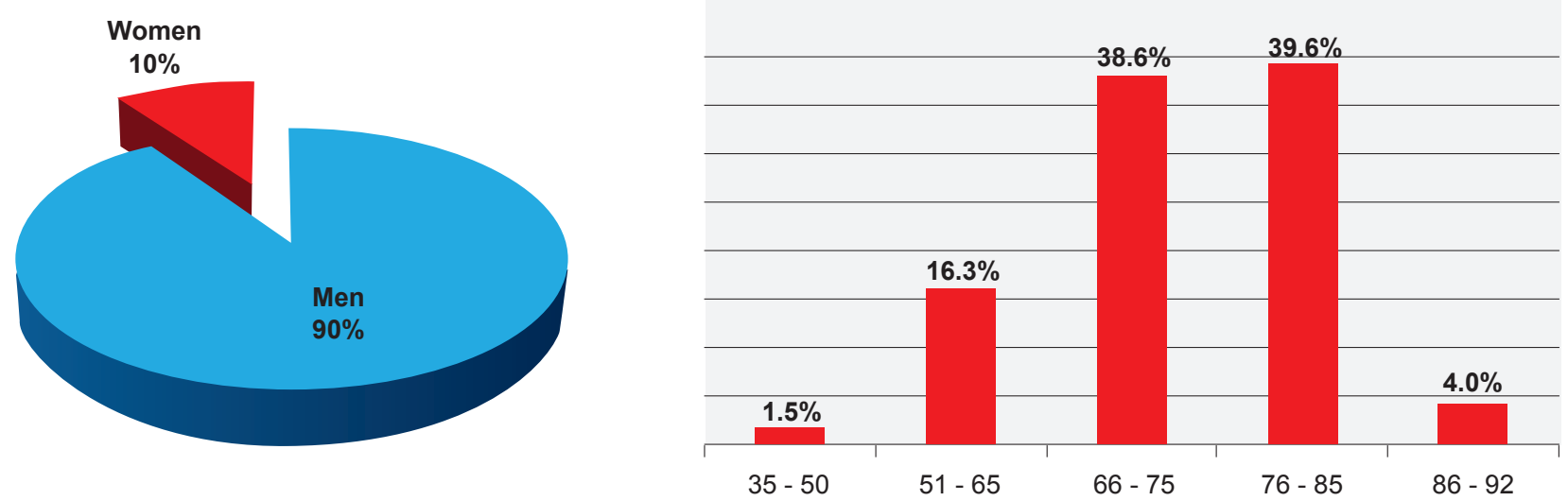

Figure 1 - Sex and age distribution of patients with endovascular repair of the aorta at our center from 2001 to 2012

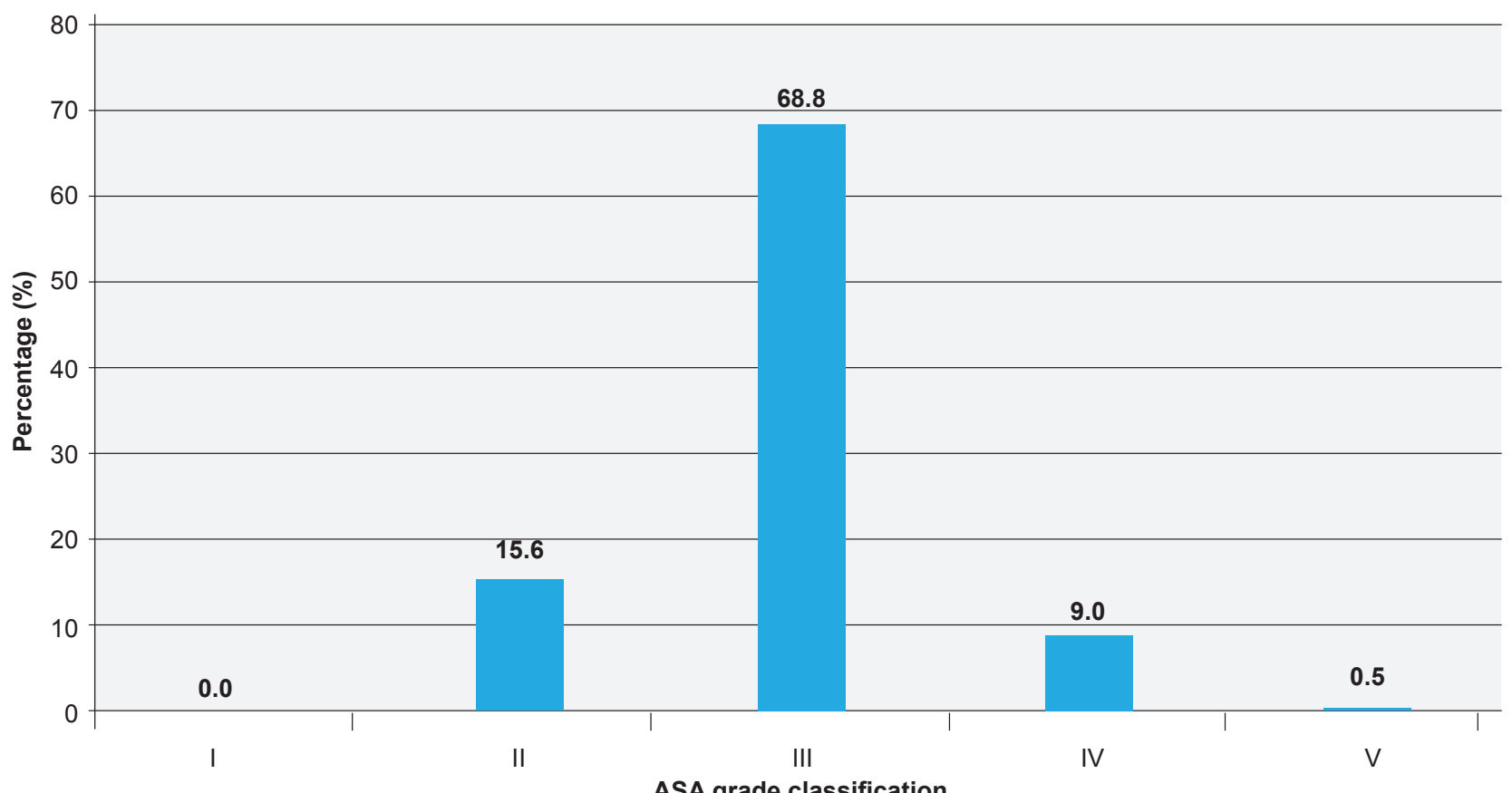

Figure 2 - ASA grading of the patients

transfused $(90 \%$ of those submitted to $A B I, 74 \%$ of the $A U I$, $60 \%$ of the THO), $8.1 \%$ of the patients needed $1 \mathrm{RBCU}$, $7.6 \%$ needed 2 RBCU and $11.7 \%$ needed 3 or more RBCU, with a maximum of $14 \mathrm{RBCU}$.

When we analyzed the relation between ASA classification and RBCU transfused we observed a statistical significant relationship $(p<0.01)$ only for transfusions after the first 24 hours.

Until 2010 we routinely crossmatch $4 \mathrm{RBCU}$ for elective EVAR and our CTR was 10.1. In 2010 we alter our policy and we started to crossmatch 2 RBCU with a CTR of 7.3 from 2011 to 2012.

The average hemoglobin concentration loss was $2.5 \mathrm{~g} /$ $\mathrm{dL}$. The average number RBCU spent in the first 24 hours of surgery has diminished over the years.

The ratios of RBCU administrated in the first 24 hours per type of procedure/endoprosthesis were 0.21 for $A B I, 0.46$ for AUI, 0.8 for THO, 1.3 for hybrid thoracic surgery and 2 for hybrid abdominal procedures. The blood consumptions for each procedure and time interval is shown in Table 1.

We had no conversion to open repair.

\section{DISCUSSION}

Overall transfusion rates in EVAR are reported to be between 4.2 to $25 \%$ and peroperative transfusion rates between 13 to $18 \%$. No official MSBOS exists for EVAR. Without a MSBOS, preoperative ordering of blood is usually based on subjective anticipation of blood loss which generally assumes the worst case assumptions and overestimates RBCU needed. MSBOS refers to a list of surgical procedures and its respective number of RBCU to be crossmatched before surgery and its implementation allowed improving blood stock management and reducing wastage of blood and resources. So each institution should create an MSBOS based on their experience and on the published literature. 
Table 1 - Prevalence of blood transfusions for each procedure during the first 24 hours

\begin{tabular}{cccccc}
\hline \multicolumn{5}{c}{ Blood used in the first 24 hours } \\
\hline RBCU & ABI & AUI & TEVAR & Hybrid TEVAR & Hybrid EVAR \\
$\mathbf{0}$ & 90.0 & 74.0 & 60.0 & 66.6 & - \\
$\mathbf{1}$ & 5.0 & 13.0 & - & 16.7 & 33.3 \\
$\mathbf{2}$ & 2.5 & 8.0 & 40.0 & - & - \\
$\mathbf{3}$ & 0.8 & 2.5 & - & 16.7 & 33.3 \\
$\mathbf{4}$ & 0.8 & 2.5 & - & - & - \\
$\mathbf{5}$ & - & - & - & - & - \\
$\mathbf{6}$ & 0.8 & - & - & - & - \\
7
\end{tabular}

ABI: aorto-bi-iliac; AUI: aorto-uni-iliac + crossover bypass; TEVAR: endovascular repair of thoracic aneurism; EVAR: endovascular repair of abdominal aortic aneurysm

Despite major complications rates such as iatrogenic rupture are very low during endovascular repair, it can lead to life-threatening bleeding and so it requires massive transfusion. All institutions must have an emergency protocol. In this situation specific blood has no additional safety benefit in comparison to $O$ negative.

In our institution, our global policy is to transfuse when hemoglobin is below $8 \mathrm{~g} / \mathrm{dL}$, except for special conditions like ischemic cardiac disease. Our protocol for emergent transfusion is 4 RBCU $O$ negative immediately available. Full crossmatched blood is available in $30 \mathrm{~min}$. We crossmatch 4 RBCU for open abdominal aortic aneurysm repair, similar to the literature. In the beginning of our EVAR program we crossmatched $4 \mathrm{RBCU}$ for patient. Due to an empirical analysis in 2010 that changed to 2 RBCU.

In 2012 there was a significant drop in blood donation in Portugal, leading to analysis of the policy for transfusion in our surgical department.

The ideal CTR would be 1 but it means that all crossmatched blood were transfused which would be unsafe. The British Committee for Standard in Haematology Blood Transfusion Task Force recommended that a CTR of 2 - 3 is acceptable which would result in $30-50 \%$ of crossmatched blood being transfused. ${ }^{11}$ Guidelines from the British Society of Haematology (BSH) are based on a CTR of 2:1 reinforcing that blood should not be available for surgery if the usage is below $50 \%$ of requested. These guidelines serve only to provide an aid but an individual decision must be performed some patients could require crossmatch blood ordering independently of the protocol such as those with antibodies found in group and save screen or those with clot disorders.

Our CTR was 10.1 until 2010 and 7.3 from 2011 to 2012, well above the recommended. The blood consumption during endovascular aortic procedures at our center was low. In fact no blood was transfused in 156 surgeries. The crossmatch of 4 RBCU implies a cost of $32 €$ and the crossmacth of $2 \mathrm{RBCU}$ has a cost of $21 €$. In the other hand, the cost of type and screen is $10 €$. Until 2010, in 104 surgeries no RBCU was used and the crossmatch of
4 RBCU represented a cost of $3328 €$. During this period, if type and screen had been performed the cost associated would have been $1040 €$, considerably lower. Between 2011 and 2012, in 52 surgeries no RBCU was used. During this period we crossmatced 2 RBCU which had an associated cost of $1092 €$, considerable higher than $520 €$ of type and screen strategy.

In the pursue for our new protocol, we assumed that a procedure with less than $0.5 \mathrm{RBCU} /$ surgery/first 24 hours in the last years doesn't need any crossmatched blood, so a type and screen strategy was to be put in place. If a procedure has a $\mathrm{RBCU} /$ surgery/first 24 hours ratio over 0.5 we crossmatch blood adapted to the type of surgery.

The ABI grafting had a $0.21 \mathrm{RBCU} /$ surgery/first 24 hours ratio, well under 0.5 . The AUI grafting associated with femoral crossover bypass presented a 0.46 blood units transfused/ surgery ratio. Since March 2013, we only type and screen patients that will be submitted to these endovascular aortic repairs (representing over $90 \%$ of endovascular surgeries).

TEVAR had a RBCU/surgery/first 24 hours ratio of 0.8 . In relation with the patient's security, we defined that $2 \mathrm{RBCU}$ should be crossmatched. When the TEVAR is associated with aortic arch debranching, our ratio was 1.3 , leading us to crossmatch $3 \mathrm{RBCU}$ before this kind of procedures. The abdominal hybrid surgery had a RBCU/surgery/first 24 hours ratio of 2 . When a patient is to undergo this surgery 4 RBCU are crossmatched.

The previous protocol is followed unless the patient has some known blood disorder or previous exposure to blood transfusions.

The relation between ASA classification, used to define perioperative risk, and blood transfusion was already mentioned in literature. ${ }^{12,13}$ In our experience ASA classification is related to postoperative blood transfusion after the first 24 hours, so it doesn't interfere with the surgical blood orders schedule. Instead it requires a close post operative control of hemoglobin levels in ASA III, IV and $\mathrm{V}$ patients.

Our recommendations are the same as Mann et al in relation to EVAR, although this previous study did not 
differentiate between $\mathrm{ABI}, \mathrm{AUI}, \mathrm{THO}$ and hybrid surgery.

\section{CONCLUSION}

The blood transfusion in endovascular aneurysm repair is very low in the $A B I$ and $A U I$ endovascular surgeries. Because of the high CTR a type and screen politic can be put in place for patients that undergo these procedures. This may lead to financial savings, improved efficiency and reduce the workload in the hematology department.

\section{PROTECTION OF HUMANS AND ANIMALS}

The authors declare that the procedures were followed according to the regulations established by the Clinical

\section{REFERENCES}

1. The United Kingdom EVAR Trial Investigators. Endovascular repair of aortic aneursm in the patients phsically ineligible for open pepair. $\mathrm{N}$ Engl J Med. 2010;362:1872-80.

2. Elkouri S, Gloviczki P, McKusick MA, Panneton JM, Andrews J, Bower TC, et al. Perioperative complications and early outcome after endovascular and open surgical repair of abdominal aortic aneurysms. J Vasc Surg. 2004;39:497-505.

3. Prinssen M, Verhoeven EL, Buth J, Cuypers PW, van Sambeek $\mathrm{MR}$, Balm R, et al. A randomized trial comparing conventional and endovascular repair of abdominal aortic aneurysms. $\mathrm{N}$ Engl $\mathrm{J}$ Med. 2004;351:1607-18.

4. Greenhalgh, R. M. Comparison of endovascular aneurysm repair with open repair in patients with abdominal aortic aneurysm (EVAR trial 1), 30-day operative mortality results: randomised controlled trial. Lancet. 2004;364:843-8.

5. David J. Minion et al. Access techniques for EVAR: Percutaneous techniques and working with Small Arteries. Semin Vasc Surg. 2012;25:208-16.

6. Montán C, Wannberg M, Holst J, Wahlgren C. Perioperative Haemorrhage in Endovascular Abdominal Aneurysm Repair Affects Outcome. Eur J Vasc Endovasc. 2013;46:87-92.

7. Newton W, Shukla M, Andrews J, Hansen K, Corriere M, Goodney P,
Research and Ethics Committee and to the Helsinki Declaration of the World Medical Association.

\section{DATA CONFIDENTIALITY}

The authors declare having followed the protocols in use at their working center regarding patient's data publication.

\section{CONFLICTS OF INTEREST}

The authors declare that there are no conflicts of interest.

\section{FUNDING SOURCES}

No subsidies or grants contributed to this work.

Edwards M. Outcomes of acute intraoperative surgical conversion during endovascular aortic aneurysm repair. J Vasc Surg. 2011;54:124450.

8. Hall TC, Pattenden C, Hollobone C, Pollard C, Dennison A. Blood transfusion in elective general surgery: how to optimise cross-match-totransfusion ratios. Transfus Med Hemother. 2013;40:27-31.

9. Belaynech T, Messele G, Abdissa Z, Tegene B. Blood requisition and utilization practite in surgical patients at University of Gondar Hospital, Northwest Ethiopia. J Blood Transfus. 2013. 2013:1-5.

10. Mann K, Sim I, Ali T, Chong P, Leopold P, Hatrick A, et al. Removing the need for crossmatched blood in elective EVAR. Eur J Vasc Endovasc Surg. 2012;43:282-5.

11. British Committee for Standard in Haematology Blood Transfusion Task Force. Guidelines for implementation of a maximum surgical blood order schedule. Clin Lab Haematol. 1990;12:321-7.

12. Odumala A, Ayekoloye C, Packer G. Predictors of excessive blood loss during operative treatment of hip fractures. Surgeon. 2002;47:552-6.

13. Han K, Kim H, Pantuck A, Dorey F, Figlin R, Belldegrun A. Use of American Society of Anesthesiologists physical status classification to assess perioperative risk in patients undergoing radical nephrectomy for renal cell carcinoma. Urology. 2004;63:841-6. 